\title{
Within- and between-tree variation of wood density components in Pinus nigra at six sites in Portugal
}

\author{
Alexandra Dias ${ }^{1} \cdot$ Maria J. Gaspar ${ }^{2,3,4} \cdot$ Ana Carvalho $^{2} \cdot$ Jani Pires $^{3} \cdot$ José Lima-Brito $^{2,3} \cdot$ Maria E. Silva $^{1,5}$. \\ José L. Louzada ${ }^{1,5}$ (D)
}

Received: 20 July 2017 / Accepted: 10 April 2018 / Published online: 8 May 2018

(C) INRA and Springer-Verlag France SAS, part of Springer Nature 2018

\begin{abstract}
- Key message In Europe, P. nigra wood presents a density pattern of longitudinal variation with an increase from east to west. However, no latitudinal tendencies were detected. Compared to other Portuguese resinous species, $P$. nigra revealed higher density, identical radial growth and intra-ring heterogeneity, which presents advantages for industry purposes. The environmental factors (Sites effect) manifest more strongly in the latewood components while the Trees/Sites effect is more strongly expressed in the earlywood components.

- Context Although P. nigra Arnold is one of the most important conifers in Europe, little is known about the wood's characteristics in the southwest European region.

- Aims Our aims are to outline a first approach to study the growth and wood quality in P. nigra in Portugal comparing to other European natural stands and other resinous species.

- Methods Inter- and intra-wood density variation of $P$. nigra from six Portuguese sites was studied using microdensitometry. Analysis of variance (ANOVA) was performed in three subsets: 50 common rings, core (juvenile wood) and peripheral analysis (mature wood). - Results The average ring density was $0.588 \mathrm{~g} \mathrm{~cm}^{-3}$, with maximum values in the north and low altitudes. Regarding growth traits, no latitudinal and altitudinal tendencies were detected. Compared to the main timber species in Portugal (P. pinaster Aiton), P. nigra showed similar radial growth, higher density but lower intra-ring density homogeneity. The Sites effect mainly influenced latewood density components, while the Trees/Sites effect primarily influenced earlywood components. The Rings effect was found to be relatively low, with a density decrease in the tree's first years followed by an increase in the periphery. Growth traits showed a reduction from pith to bark.

- Conclusion Considering the quality (density) and growth features of the Black pine, this species could be useful for the reforestation of mountainous Southern Europe areas that are not favourable for other species.
\end{abstract}

Keywords Black pine $\cdot$ Wood variation $\cdot$ Microdensitometry $\cdot$ Juvenile wood $\cdot$ Mature wood

Handling Editor: Jean-Michel Leban

Contributions of the co-authors Conceived and designed the experiments: JLL, MJG, JLB; performed the experiments: AD, JP, AC; acquisition and analysis of the data: JLL, AD, JP, MES; wrote the paper: AD, JLL, MES; supervising the work: JLL, MJG, AC, JLB; critical revision of the manuscript: JLL, MES, MJG.

\section{José L. Louzada}

jlousada@utad.pt

1 Centre for the Research and Technology of Agro-Environmental and Biological Sciences (CITAB), University of Tras-os-Montes and Alto Douro, 5001-801 Vila Real, Portugal

2 BioISI-Biosystems and Integrative Sciences Institute, Faculty of Sciences University of Lisboa, C8 BDG Campo Grande, Lisbon, Portugal
3 Department of Genetics and Biotechnology (DGB), University of Tras-os-Montes and Alto Douro, 5001-801 Vila Real, Portugal

4 Centre of Forestry Studies (CEF), Instituto Superior de Agronomia, Universidade Técnica de Lisboa, Tapada da Ajuda, 1349-017 Lisbon, Portugal

5 Department of Forestry Sciences and Landscape (CIFAP), University of Tras-os-Montes and Alto Douro, 5001-801 Vila Real, Portugal 


\section{Introduction}

The discontinuous distribution of $P$. nigra Arnold ranges from Southern Europe to Asia Minor, reaching North-west Africa (Little and Critchfield 1969; Rubio-Moraga et al. 2012) and the islands of Corsica and Sicily (Rubio-Moraga et al. 2012). In Iberian Peninsula forests, this species natural presence is restricted to Spain, and it occupies one of the largest high mountain areas in a wide latitudinal and longitudinal gradient (Barbéro et al. 1998; Génova and Fernandéz 1998; Rubiales et al. 2010), presenting high resistance to low temperatures and dry conditions (Génova 2000; Climent et al. 2009). In Portugal, existent populations resulted from afforestation performed 50 to 90 years ago in the north and central regions (Louro 1982), being the P. nigra populations located in the extreme west of Europe.

Distinct environmental conditions, competition, stand structure (Piutti and Cescatti 1997), drought, tree bionomics and human activity are factors that can influence radial growth (Koprowski and Duncker 2012) and wood properties (Downes et al. 2000; Zobel and Van Buijtenen 1989). Among these properties, wood density is considered the most important due to its correlation with other physical properties such as mechanical strength and workability (Louzada and Fonseca 2002; Knapic et al. 2007).

Wood density is extremely variable among species, sites and between and within trees (Louzada 2003). Large rings with low density are usually associated with juvenile wood, while small rings with high density are typical of mature wood (Zobel and Sprague 1998). At the microscopic level, juvenile wood characteristics are due to the existence of large earlywood cells, formed during spring, with thin tracheid walls caused by rapid growth and lower competition with other trees. In the mature wood, there is a larger proportion of latewood cells formed in summer with thicker cell walls (Lebourgeois 2000; Gryc et al. 2011; Li et al. 2011). For this reason, in conifers, wood density is usually lower near the pith (juvenile wood), followed by a rapid increase, then a subsequent slowing until almost constant values are reached in the mature wood zone (Pearson and Ross 1984; Zobel and Sprague 1998).

The characteristic lower density of juvenile wood imparts advantages for its use for processed wood technology, such as paper or agglomerated materials, due to its lower resistance and energy demands (Gryc et al. 2011). However, its lower density, shorter fibres, low cellulose content and greater presence of knots have an impact on its end-use properties, mainly timber stiffness, making it inappropriate for solid timber production (Xu et al. 2004; Gapare et al. 2006; Wu et al. 2007).

Site is one of the factors that strongly affect wood density in pine species (Zobel and Talbert 1984). Nevertheless, at the same site, density varies between trees and within the tree (Louzada 2000).
Understanding the variability of wood features (i.e., density and growth) of a species not only allows the comprehension of wood development conditions but also enables the improvement of wood quality, processing and use (Fernandéz et al. 1996; Lebourgeois 2000; Fernández-Golfín et al. 2001; Koga and Zhang 2004; Guler et al. 2007; Wils et al. 2009; Köse et al. 2012; Martín-Benito et al. 2010b, 2012; Guller et al. 2012). Since Portugal constitutes the southwest extreme limit of $P$. nigra's distribution area, the species faces different edaphoclimatic conditions, which may affect its wood characteristics.

The main timber species in Portugal is $P$. pinaster, which occupies a major part of the interior forest area up to $800 \mathrm{~m}$ in altitude, with the mountain range above this point largely deforested. Moreover, in recent decades, the forest area in which $P$. pinaster is found has been significantly reduced (ICNF 2013). In this sense, reforestation of Portuguese highaltitude mountainous regions with P. nigra could be important to supply timber demand and could become a major source of direct and indirect resources, not only for local populations but also for the Portuguese forestry sector. Analysis of P. nigra wood can allow inferences about its use as a timber species in Portugal.

The overall objective of this study is to assess inter- and intra-tree wood variation in P. nigra trees growing in Portugal, as part of an evaluation of the technological quality of their wood and timber potential for possible use in the reforestation of Portuguese mountainous areas. Additionally, this study aims to answer the following:

- Does Portuguese P. nigra wood differ from that of other European natural stands?

- Does Portuguese P. nigra wood differ from P. pinaster wood (a resinous species mainly used for wood industry purposes in Portugal) and other European resinous species (imported to satisfy the softwood national demand)?

\section{Materials and methods}

\subsection{Sites and plant material}

Samples were collected in six pure, even-aged stands representative of the P. nigra Portuguese population, mainly situated in the north and centre of the country (Fig. 1). The sites are located in high mountain ranges between 450 and $1600 \mathrm{~m}$ in altitude.

For each site, one sample plot of 0.04 ha was established. Dendrometric measurements were performed for all trees in each plot, and a total of 90 dominant or codominant trees, 15 per plot, were harvested (Table 1). For each harvested tree, two $12-\mathrm{mm}$ wood cores from bark to pith were collected at 
$1.3 \mathrm{~m}$ above ground and chosen the core that presented lower reaction wood.

Two-mm strips were cut from the wood cores and conditioned at $12 \%$ moisture content. The samples were X-rayed perpendicularly to the transverse section, and the images were scanned for densitometric analysis (Polge 1966; Louzada 2000). The radiation had an intensity of $18 \mathrm{~mA}$, exposure time of $300 \mathrm{~s}$ and accelerating tension of $12 \mathrm{kV}$, with a $2.5 \mathrm{~m}$ distance between the X-ray source and the film. Data from the radial density profiles were recorded every $100 \mu \mathrm{m}$ with a tangential direction of $455 \mu \mathrm{m}$. To convert the optical density to real density, standards of cellulose acetate were X-rayed with different thicknesses and known real densities that allowed linear regression through the calculation of these values. The first and last annual rings were excluded because these are usually incomplete (Gaspar et al. 2008; Gaspar et al. 2009; Louzada 2003). The remaining ring boundaries were identified through visual observation of their microscopic anatomical characteristics (i.e., cell wall thickness and lumen diameter). The density components calculated were as follows: average ring density (RD), minimum density (MND), maximum density (MXD), earlywood density (EWD), latewood density (LWD), latewood percentage (LWP), earlywood width (EWW), latewood width (LWW), ring width (RW) and heterogeneity index (HI). As suggested by Ferrand (1982), HI is defined as the standard deviation of all density values through the annual ring. The limit between earlywood and latewood for each ring is determined by the average of the minimum and maximum density values within the ring (Mothe et al. 1998; Rozenberg et al. 2001).

Data availability The datasets generated during the current study are available in Figshare repository [www.figshare. com]:

- https://figshare.com/s/6803bf8e12a5899dd36e

- https://figshare.com/s/3cfe302a27b7119ef06a

- https://figshare.com/s/ef31cb407e0e8920037a

- https://figshare.com/s/f920ef518792c8ced9bd

- https://figshare.com/s/3d2a7623b1d65382a563

- https://figshare.com/s/f3b555d87745c0485a9a

- https://figshare.com/s/d35c705c68a789c3b9c9

\section{Data analysis}

Variance analysis of the density and growth components was accomplished according to the model presented in Table 2 to test the significance of sites, trees (random effect), rings (cambial age) and their interactions and to calculate the expected variance of each source of variation. To perform the statistical analysis, JMP Statistical Software (SAS Institute Inc.) was used.
The present work was carried out for the wood microdensitometric profile from pith to bark, for all trees. The different chronological ages of the individual specimens required division of the analysis into subsets to orthogonalize the data and increase information in terms of wood variation within and between trees. The first group comprises the 50 initial growth rings from the pith for common analysis, and the second group comprises the 25 initial growth rings from the pith for core analysis, where the growth rings have the same cambial age, which is representative of juvenile wood (Mutz et al. 2004). The third subset approaches the peripheral analysis and comprises the last 25 rings with same chronological age, which is characteristic of mature wood. In this case, the source of variation Rings is replaced by Years (chronological age).

To study the dispersion/association patterns among different components of wood density, growth and climatic data, principal component analysis was performed with StatView 5.0 software (SAS Institute Inc.). Additionally, multivariate discriminant analysis was conducted to provide a global view of the variation structure of wood properties and climatic factors using Statistica 6.0 software (StatSoft, Inc). This analysis was performed with all wood components at the tree level and grouped by sites and the annual climatic variable.

\section{Results}

Data concerning the mean values of wood density components are presented in Table 3, with subsets of data for the 50 initial rings (common), the 25 initial rings (core) and the 25 final rings (peripheral) from 90 trees, which are representative of the six sites.

\subsection{General analysis}

The RD of the overall sites in the present study is $0.588 \mathrm{~g} \mathrm{~cm}^{-3}$, with an EWD of $0.481 \mathrm{~g} \mathrm{~cm}^{-3}$, LWD of $0.763 \mathrm{~g} \mathrm{~cm}^{-3}$ and HI of $0.150 \mathrm{~g} \mathrm{~cm}^{-3}$. Concerning radial growth traits, Portuguese $P$. nigra wood presented a mean RW of $2.43 \mathrm{~mm}$ (1.56 $\mathrm{mm}$ of EWW and $0.87 \mathrm{~mm}$ of LWW), corresponding to a LWP of $38.9 \%$. Figures 2, 3 and 4 present the radial trends (from pith to bark) of the ring density components, HI and growth components, respectively.

\subsection{Comparison among Portuguese sampling sites}

Based on the density components (RD, EWD and LWD) in Table 3, the sites with higher density values are Paredes de Coura and Caminha (altitude of 451 and $443 \mathrm{~m}$ ), while Manteigas and Vale do Zêzere (altitude of 1144 and $1560 \mathrm{~m}$ ) present the lowest values. It is possible to verify a tendency toward a decrease in density with an increase in altitude (Fig. 5a). Regarding latitude, the lowest density values are 


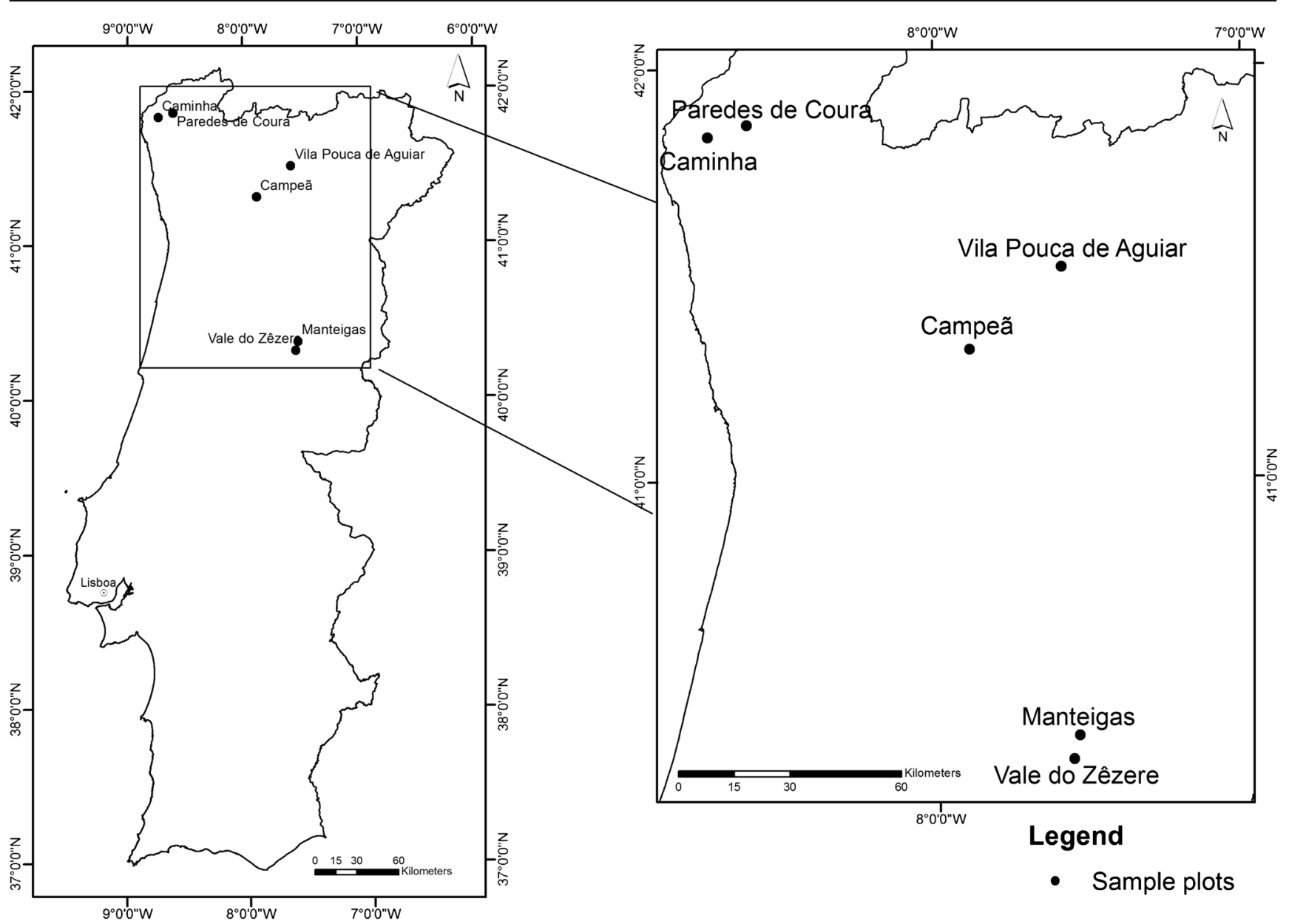

Fig. 1 Sampling sites of the six representative Portuguese P. nigra populations

obtained in Manteigas and Vale do Zêzere (geographically close in the south), while higher density values are present in Paredes de Coura and Caminha (closely situated in the north). This indicates a tendency for density to increase along with latitude (Fig. 5b).

Concerning growth components, the highest values were observed in Caminha, Campeã and Vila Pouca de Aguiar, and the lowest values in Paredes de Coura and Manteigas. No tendencies were identified in terms of latitude and altitude (Fig. 5c, d).

Figure 6 shows the regression between RD and RW vs precipitation $(\mathrm{R})$, average temperature $(\mathrm{T})$, minimum temperature (Tmin) and maximum temperature (Tmax), where the effects of the climatic data were expressed more strongly in RD than in RW. Additionally, among sites, no significant correlation was detected between RW and RD (Fig. 7).

HI quantifies the within-rings density variability, which was higher in Caminha for all three subset analyses. The lowest HI was in Campeã and Vale do Zêzere for the common and core analysis. For the peripheral analysis, the lowest HI was in Manteigas and Vila Pouca de Aguiar.

Figure 8 presents the distribution pattern of the wood and climatic components obtained by the first two factors of the principal component analysis, which explain $75.6 \%$ of the total variation.

\subsection{Within- and between-tree variation}

The ANOVA of the wood density components for the common rings (1-50), core rings (1-25) and peripheral rings (outer 25) subsets are summarized in Table 4.

\subsubsection{Common rings analysis}

The Sites effect explains $9.11 \%$ of the RD variability, which results in different $\mathrm{RD}$ among sites. This was found to be the highest for Paredes de Coura and Caminha (0.644 and $0.636 \mathrm{~g} \mathrm{~cm}^{-3}$ ) and lowest for Manteigas and Vale do Zêzere $\left(0.534\right.$ and $\left.0.541 \mathrm{~g} \mathrm{~cm}^{-3}\right)$. The differences between sites are higher for the latewood components $\operatorname{MaxD}(6.82 \%)$ and LWD $(7.35 \%)$ than for the earlywood components MinD $(4.33 \%)$ and EWD (4.9\%). The Sites effect of HI has a value of $5.74 \%$. Regarding the growth components, RW, EWW and LWW are influenced by the Sites effect between 5.23 and $9.27 \%$. Concerning LWP, this explains $13.59 \%$ of the total variation. 
Table $1 \quad$ P. nigra sampled sites and dendrometric data

\begin{tabular}{|c|c|c|c|c|c|c|}
\hline & Paredes de Coura & Caminha & $\begin{array}{l}\text { Vila Pouca de } \\
\text { Aguiar }\end{array}$ & Campeã & Manteigas & Vale do Zêzere \\
\hline Number of individuals & 15 & 15 & 15 & 15 & 15 & 15 \\
\hline Coordinates & $\begin{array}{l}41^{\circ} 52^{\prime} 0.00^{\prime \prime} \mathrm{N} \\
8^{\circ} 36^{\prime} 21.00^{\prime \prime} \mathrm{W}\end{array}$ & $\begin{array}{l}41^{\circ} 50^{\prime} 15.00^{\prime \prime} \mathrm{N} \\
8^{\circ} 43^{\prime} 57.00^{\prime \prime} \mathrm{W}\end{array}$ & $\begin{array}{l}41^{\circ} 31^{\prime} 02.72^{\prime \prime} \mathrm{N} \\
7^{\circ} 35^{\prime} 31.36^{\prime \prime} \mathrm{W}\end{array}$ & $\begin{array}{l}41^{\circ} 19^{\prime} 9.12^{\prime \prime} \mathrm{N} \\
7^{\circ} 53^{\prime} 28.35^{\prime \prime} \mathrm{W}\end{array}$ & $\begin{array}{l}40^{\circ} 22^{\prime} 47.00^{\prime \prime} \mathrm{N} \\
7^{\circ} 33^{\prime} 18.00^{\prime \prime} \mathrm{W}\end{array}$ & $\begin{array}{l}40^{\circ} 19^{\prime} 19.00^{\prime \prime} \mathrm{N} \\
7^{\circ} 34^{\prime} 26.00^{\prime \prime} \mathrm{W}\end{array}$ \\
\hline Average age \pm SD & $57.8 \pm 1.1$ & $57.9 \pm 1.3$ & $74.7 \pm 2.9$ & $58.1 \pm 1.5$ & $93.3 \pm 2.8$ & $59.1 \pm 1.6$ \\
\hline Average height (m) & 14.8 & 26.3 & 26.8 & 23.1 & 24.4 & 15.0 \\
\hline $\begin{array}{l}\text { Average diameter at } \\
1.3 \mathrm{~m}(\mathrm{~cm})\end{array}$ & 21.1 & 32.6 & 40.1 & 37.1 & 34.1 & 24.8 \\
\hline $\begin{array}{l}\text { Stand density } \\
\text { (trees/ha) }\end{array}$ & 975 & 725 & 475 & 650 & 525 & 700 \\
\hline Altitude & 451 & 443 & 908 & 891 & 1144 & 1560 \\
\hline $\begin{array}{l}\text { Annual mean } \\
\text { precipitation }(\mathrm{mm})^{*}\end{array}$ & 1462 & 1276 & 1215 & 1349 & 1890 & 1710 \\
\hline $\begin{array}{l}\text { Annual mean } \\
\text { temperature }\left({ }^{\circ} \mathrm{C}\right)^{*}\end{array}$ & 13.3 & 14.7 & 12.1 & 12.1 & 9.2 & 7.8 \\
\hline $\begin{array}{l}\text { Annual min } \\
\text { temperature }\left({ }^{\circ} \mathrm{C}\right)\end{array}$ & 9.3 & 11.2 & 7.1 & 7.0 & 5.5 & 4.3 \\
\hline $\begin{array}{l}\text { Annual max } \\
\text { temperature }\left({ }^{\circ} \mathrm{C}\right)\end{array}$ & 17.4 & 18.2 & 17.1 & 16.8 & 13.5 & 11.4 \\
\hline $\begin{array}{l}\text { Köpen-Geiger climate } \\
\text { classification* }\end{array}$ & $\mathrm{Csb}$ & $\mathrm{Csb}$ & $\mathrm{Csb}$ & $\mathrm{Csb}$ & $\mathrm{Csb}$ & $\mathrm{Csb}$ \\
\hline Soil type** & $\begin{array}{c}\text { Umbric Cambisols } \\
\text { derived schists }\end{array}$ & $\begin{array}{l}\text { Umbric Regosols } \\
\text { derived granites }\end{array}$ & $\begin{array}{c}\text { Umbric Cambisols } \\
\text { derived schists }\end{array}$ & $\begin{array}{c}\text { Umbric Cambisols } \\
\text { derived schists }\end{array}$ & $\begin{array}{l}\text { Umbric Regosols } \\
\text { derived granites }\end{array}$ & $\begin{array}{l}\text { Umbric Regosols } \\
\text { derived granites }\end{array}$ \\
\hline Soil horizon** & AhBwCR & AhCR & $\mathrm{AhBwCR}$ & AhBwCR & AhCR & AhCR \\
\hline
\end{tabular}

*http://pt.climate-data.org; Csb-Warm and temperate climate

**FAO/ISRIC/ISSS, 1998: World Reference Base for Soil Resources. World Soil Resources Report 84. FAO, Rome, 88p.

The Trees within Sites (Trees/Sites) effect is the main source of variation for wood density in the common rings analysis, representing $67.27 \%(\mathrm{RD})$ to $72.6 \%$ (MaxD) of the total variation, with similar influence for the earlywood and latewood components. In the HI, this source of variation explains $66.49 \%$ of the variance, meaning that trees show different patterns of within-ring wood density variation. In other words, some specimens show high density variation between earlywood and latewood, while others present low within-ring variation.

In the case of the growth components, the Trees/Sites effect explains $33.95 \%$ (RW), 33.03\% (EWW), 34.06\% (LWW) and
$41.76 \%$ (LWP) of total variation, comprising the highest sources of variation.

The Rings (cambial age) effect explained $6.88 \%$ of the RD and was more significant for the earlywood components, with values of $5.39 \%(\mathrm{MinD})$ and $4.38 \%$ (EWD), than in the latewood components, with values of $1.52 \%$ (MaxD) and $2.44 \%$ (LWD). This source of variation is due to the radial pattern shown in Fig. 2.

The Rings effect on the LWP is $13.94 \%$ due to the tendency to increase from pith to bark and $4.64 \%$ on HI, as shown in Fig. 3.
Table 2 Model for ANOVA used for each density and growth components

\begin{tabular}{llll}
\hline Source of variation & Degrees of freedom & C.T. & Expected mean squares \\
\hline (1) Sites (S) & $s-1$ & $(2)$ & $\sigma^{2} \varepsilon+\mathrm{r} \sigma^{2} \mathrm{~T} / \mathrm{S}+\operatorname{tr}^{2} \mathrm{~S}$ \\
(2) Trees/Sites (T/S) & $(t-1) s$ & $(5)$ & $\sigma^{2} \varepsilon+\mathrm{r} \sigma^{2} \mathrm{~T} / \mathrm{S}$ \\
(3) Rings (R) & $r-1$ & $(5)$ & $\sigma^{2} \varepsilon+\mathrm{ts} \mathrm{k}^{2} \mathrm{R}$ \\
(4) Rings $\times$ Sites $(\mathrm{R} \times \mathrm{S})$ & $(r-1)(s-1)$ & $(5)$ & $\sigma^{2} \varepsilon+\mathrm{tk}^{2} \mathrm{RS}$ \\
$(5)$ Residual $(\mathrm{R} \times \mathrm{T} / \mathrm{S})$ & $(r-1)(t-1) \mathrm{s}$ & & $\sigma^{2} \varepsilon$ \\
\hline
\end{tabular}

$s$ number of sites, $t$ number of trees within the site, $r$ number of rings within tree, C.T. component term for calculation of the ratios of variance $(\mathrm{F}), \sigma^{2}$ estimate of the "variance" of casual sources

$k^{2}$ estimate of the "variance" of fixed sources

Note: In the peripheral analysis, the source of variation Rings is replaced by Years 


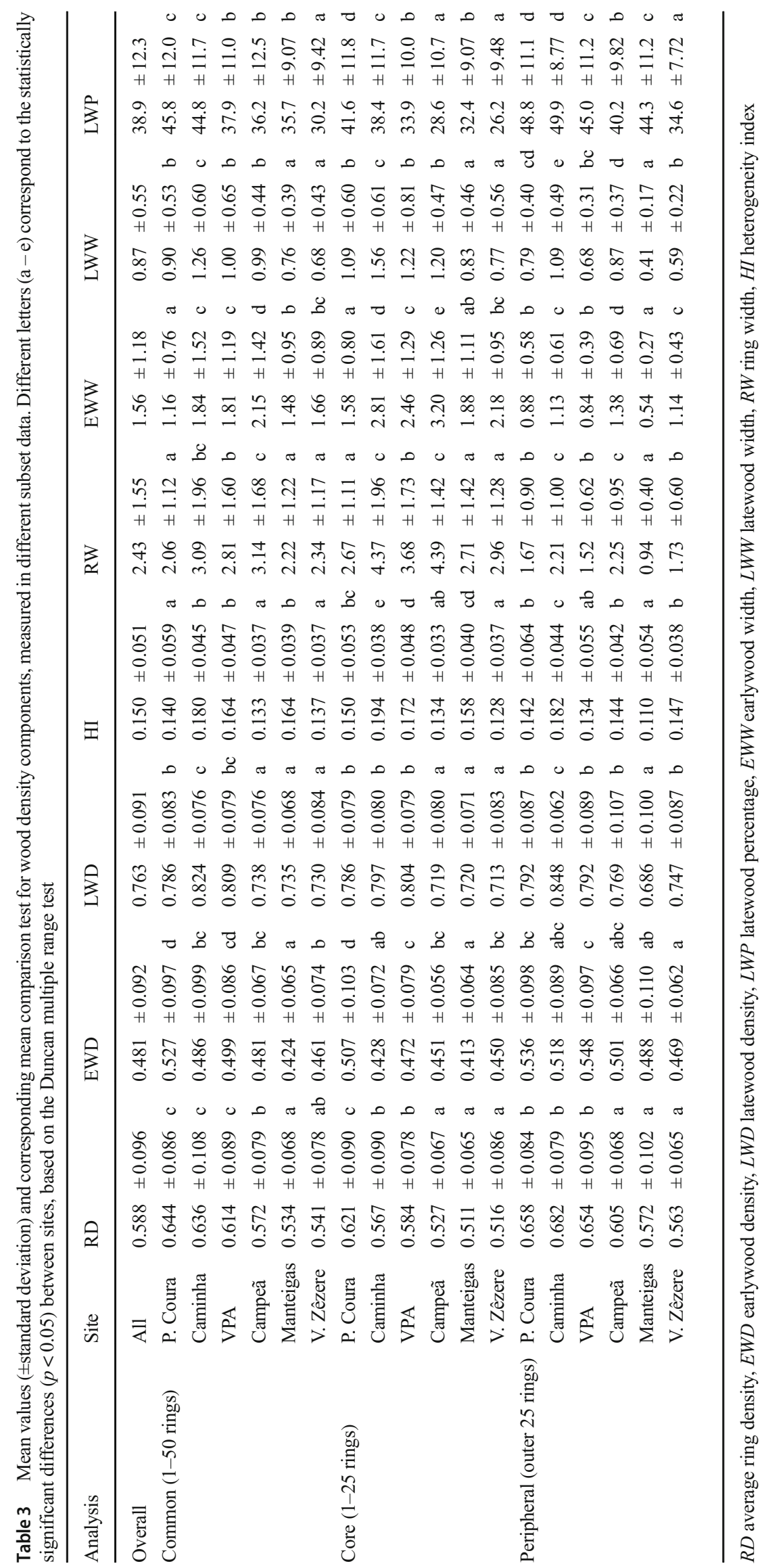


Fig. 2 Radial variation of the ring density components (RD, EWD and LWD). The lines represent the average values of all sampled trees/sites



Although the Ring effects has low influence on the density components, it represents a high source of variation for the growth components $(32.83 \%$ for EWW, 32.48\% for RW and $17.92 \%$ for LWW), which is visible in the radial tendency, with higher values in the first rings that reduce with age (Fig. 4).

The interaction between the Rings $\times$ Sites $(\mathrm{RxS})$ effects is generally low (1.86 to $3.17 \%$ ), meaning that the pattern of radial density variation is identical among sites. A similar situation occurs for the growth characteristics, except for EWW and RW, which presented slightly higher effects although they do not exceed $7.3 \%$.

The residual values explain other effects that are not considered in the sources of variation and range from 13.56 to $17.12 \%$ for the density components and from 21.04 to $35.66 \%$ for the growth components.

\subsubsection{Core rings analysis}

Core analysis results are similar to the common ring analysis. However, the Sites effect is slightly higher for the wood density components (6.93 to $13.84 \%$ ) and wood growth components (14.14 to $16.81 \%)$.

The Trees/Sites factor remains the main source of variation of wood density and growth components with 54.06 to $64.38 \%$ and 25.21 to $32.43 \%$, respectively.

Concerning the Rings effect, it accounted for only 1.95 to $9.60 \%$ for the density components and 9.48 to $19.50 \%$ for the growth components, where juvenile wood is present.

\subsubsection{Peripheral rings analysis}

As expected, as this analysis is confined to mature wood, the radial variation (Years) has less effect on the density components $(0.95$ to $2.43 \%)$, which is expressed by a stabilizing trend. The same tendency was observed for the growth traits
(2.74 to $9.55 \%$ ), corresponding to small fluctuations of the rings' width, which is characteristic of the mature wood.

Facing a reduction in the Years effect, an increase can be observed in the Sites effect, namely for the latewood components (MaxD: 13.93\% and LWD: 12.32\%), and the Trees/ Sites effect expressed mainly in the earlywood components (MinD: 85.50\% and EWD: 85.86\%). Similar trends were detected for the growth components.

\section{Discussion}

\subsection{General analysis}

Portuguese $P$. nigra wood shows an average RD value of $0.588 \mathrm{~g} \mathrm{~cm}^{-3}$, EWD of $0.481 \mathrm{~g} \mathrm{~cm}^{-3}$, LWD of $0.763 \mathrm{~g} \mathrm{~cm}^{-3}$ and $\mathrm{HI}$ of $0.150 \mathrm{~g} \mathrm{~cm}^{-3}$. A list of other studies on the same species and other European resinous species used by Portuguese wood industries is shown in Tables 5 and 6.

Studies have been performed on P. nigra from other European regions. In Turkey, P. nigra populations presented RD values from 0.464 to $0.599 \mathrm{~g} \mathrm{~cm}^{-3}$, although the lower values belong to juvenile trees. Similar density values $(0.525$ and $0.535 \mathrm{~g} \mathrm{~cm}^{-3}$ ) were obtained in Greece. Regarding Western Europe, in Spain, the results ranged from 0.558 to $0.673 \mathrm{~g} \mathrm{~cm}^{-3}$, similar to the present study $\left(0.588 \mathrm{~g} \mathrm{~cm}^{-3}\right)$. For the present results, no east to west gradient was detected, which indicates that the age effect is possibly the main cause of the observed differences. A density gradient is usually related with differences in latitude, with an increase of the density values reaching further south (Cown 1974; Tsoumis and Panagiotidis 1980). In available studies for comparison by Pazdrowski (2004) in Poland and Amarasekara and Denne (2002) in Wales, the density values were obtained indirectly by correlation, which hampers accurate comparison with the present results. The remaining mentioned studies (Table 5) are 
Fig. 3 Radial variation of the heterogeneity index (HI). The line represents the average values of all sampled trees/sites

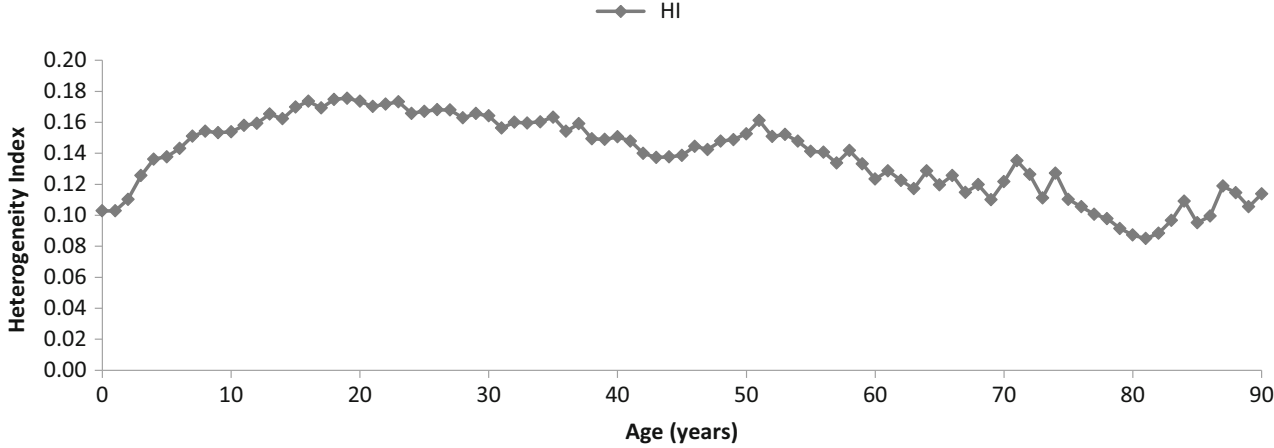

located at similar latitude values, which precludes the evaluation of this effect.

Compared to other European conifers, the RD values are generally lower than those for Portuguese $P$. nigra $\left(0.588 \mathrm{~g} \mathrm{~cm}^{-3}\right)$. P. sylvestris presented values of 0.362 to $0.552 \mathrm{~g} \mathrm{~cm}^{-3}, P$. radiata from 0.436 to $0.508 \mathrm{~g} \mathrm{~cm}^{-3}$, P. brutia from 0.495 to $0.496 \mathrm{~g} \mathrm{~cm}^{-3}, P$. abies from 0.300 to $0.516 \mathrm{~g} \mathrm{~cm}^{-3}$ and A. balsamea with $0.351 \mathrm{~g} \mathrm{~cm}^{-3}$. Similar values to Portuguese $P$. nigra were obtained only for mature P. pinaster trees $\left(0.535\right.$ to $\left.0.567 \mathrm{~g} \mathrm{~cm}^{-3}\right)$ and L. decidua $(0.573$ to $0.652 \mathrm{~g} \mathrm{~cm}^{-3}$ ).

The earlywood anatomy, with large diameter tracheids with thin cell walls, causes a decrease of density (Toïgo et al. 2015), while the latewood presents thick tracheids walls and small lumen diameter (Louzada 2000; Gryc et al. 2011). Therefore, for Portuguese P. nigra, EWD is $0.481 \mathrm{~g} \mathrm{~cm}^{-3}$ and LWD is 0 . $763 \mathrm{~g} \mathrm{~cm}^{-3}$. In relation to other conifers, lower values were found for P. sylvestris, P. brutia, P. abies and A. balsamea and identical values for mature $P$. pinaster trees, similar to the RD results.

$\mathrm{HI}$ reflects the density variability within the growth rings. It comprises one of the most important wood characteristics, which confers uniformity at the intra-ring level (Louzada 2003). In this study, the average HI value is $0.150 \mathrm{~g} \mathrm{~cm}^{-3}$, which is identical to that of mature $P$. pinaster trees $(0.140$ to $\left.0.185 \mathrm{~g} \mathrm{~cm}^{-3}\right)$ but higher than that of juvenile $P$. pinaster wood (0.120 to $0.134 \mathrm{~g} \mathrm{~cm}^{-3}$ ) and A. balsamea $\left(0.079 \mathrm{~g} \mathrm{~cm}^{-3}\right)$.

In regard to the radial growth traits (Table 6), mean RW is $2.4 \mathrm{~mm}$, of which $1.6 \mathrm{~mm}$ corresponds to EWW and $0.9 \mathrm{~mm}$ to LWW, corresponding to a LWP of $38.9 \%$. This RW value is higher than that of $P$. nigra of other regions ( 0.5 to $2.2 \mathrm{~mm}$ ), $P$. sylvestris (1.0 to $1.4 \mathrm{~mm})$ and $P$. abies $(1.5 \mathrm{~mm})$ of similar age but lower or similar than $P$. brutia $(2.2$ to $3.7 \mathrm{~mm})$, P. pinea (2.8 to $3.4 \mathrm{~mm}), P$. pinaster (2.2 to $5.1 \mathrm{~mm}), A$. balsamea $(2.1 \mathrm{~mm})$ and L. decidua $(2.4 \mathrm{~mm})$. The highest values were observed in younger trees. An identical situation was detected for EWW, LWW and LWP.

Finally, based on the wood and climate characteristics presented in Tables 5 and 6, several simple regression analyses were performed to evaluate the climate effect on wood properties (RD and RW). The statistically significant results are presented in Fig. 9. In general, these regressions show that the different species analyzed reveal a tendency toward an increase of RD with temperature as well as a decrease of RW with altitude.

\subsection{Comparison among Portuguese sampling sites}

This study does not allow a reliable analysis of altitude and latitude effects, due to the reduced number of
Fig. 4 Radial variation of the ring growth components (RW, EWW and LWW). The lines represent the average values of all sampled trees/sites. RW represents the sum of EWW and LWW

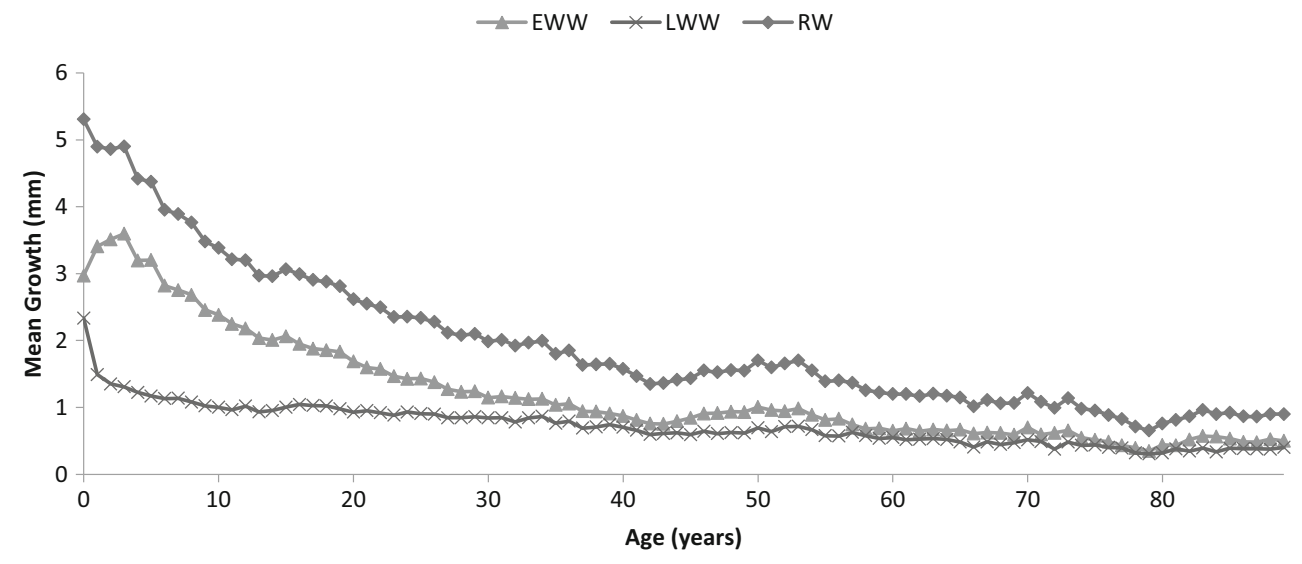




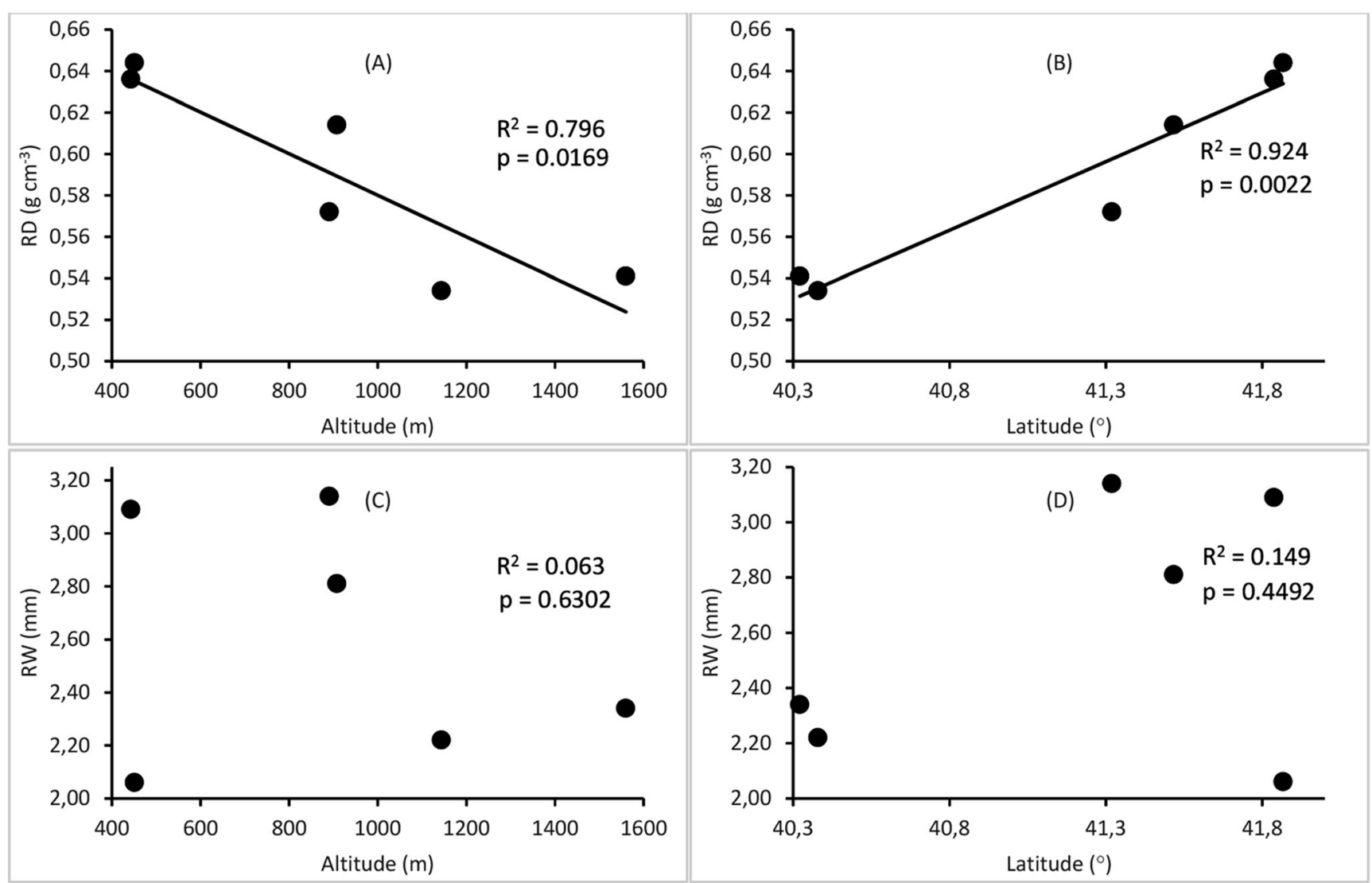

Fig. 5 Linear regression between wood components at the site level. a RD vs altitude; $\mathbf{b}$ RD vs latitude; $\mathbf{c}$ RW vs altitude; $\mathbf{d}$ RW vs latitude

stands and lack of similar geographical conditions. Therefore, it is necessary to be cautious in the interpretation of the results and posterior confirmation in wider sampling. The general tendencies were analyzed and although the sample sites have similar Köpen-Geiger climate classification, soil horizon and type, higher density values (RD, EWD and LWD) were observed at lower altitudes. These results agree with the literature on the subject, which infers that conifers density decreases with an increase in altitude (Cown 1974; Boden 1982). Furthermore, density seems to increase with latitude, which disagrees with the literature (Elliott 1970; Van der Maaten-Theunissen et al. 2013; Rossi et al. 2015). However, due to the proximity of the sites, this effect may overlap others such as the altitude, as mentioned previously.

In regard to the growth components, no tendencies in terms of latitude and altitude were observed. Although some exceptions may occur, such as Paredes de Coura, in general, sites with higher density values are positively related to higher growth rates (though not statistically significant). Optimal climatic conditions (water availability in the summer) increases the LWW, which consequently results in higher RW and RD in Picea abies (Steffenrem 2008), as well as in P. nigra, P. sylvestris, P. uncinata
(Andreu et al. 2007) and P. pinaster (Bogino and Bravo 2008; Gaspar et al. 2009). A study by Lebourgeois (2000) indicated that the LWW seems to be more sensitive to climate variations than EWW, which may also be one of the causes for the detected differences between sites. In the present study, the results seem to follow this tendency, except in Paredes de Coura as mentioned before. Here, the climatic conditions are apparently favourable, namely the annual mean precipitation and temperature (RW vs R and T-Fig. 6), but other factors may have influenced the trees' growth, such as the thin layered soil profile, due to the location on the peak of the mountain.

Concerning the climatic effect (temperature and precipitation), stronger relationships were observed with RD (usually statistically significant) than with RW (Fig. 6). This relationship is traduced by a negative tendency of precipitation in the $\mathrm{RD}$ and $\mathrm{RW}$, while the temperature effect was positive.

To confirm the weak but positive relationship between RD and RW (Fig. 7), it would be possible to conciliate good radial growth (RW) with wood quality (RD), making $P$. nigra a mountain species fit for use in general applications (namely timber wood), analogous to $P$. pinaster.

$\mathrm{HI}$ quantifies the intra-ring density variability and is higher in Caminha (0.182 to $\left.0.194 \mathrm{~g} \mathrm{~cm}^{-3}\right)$ for all three subset 

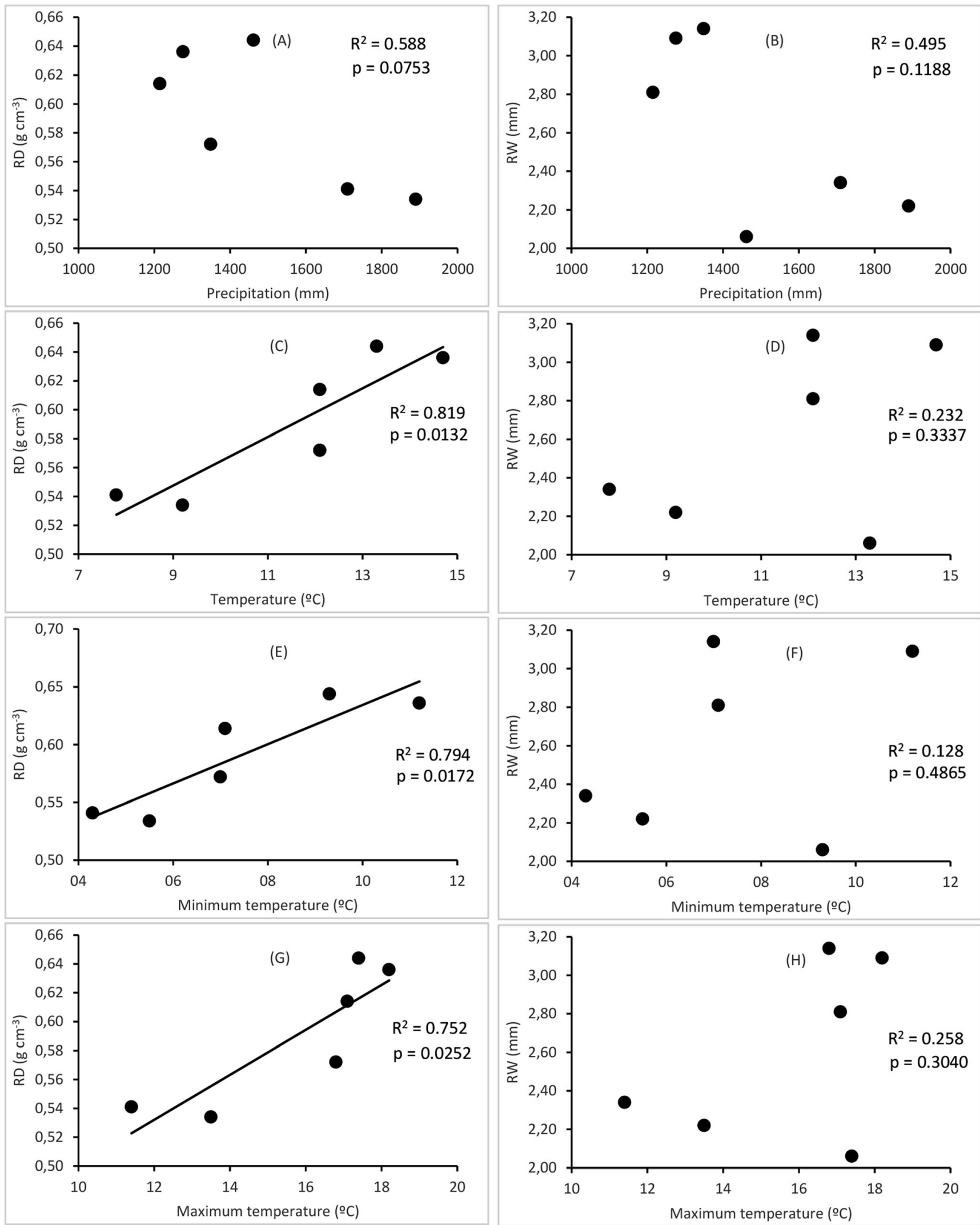

Fig. 6 Linear regression between wood components and climatic factors at the site level. a RD vs precipitation; $\mathbf{b}$ RW vs precipitation; $\mathbf{c} \mathrm{RD}$ vs temperature; $\mathbf{d}$ RW vs temperature; $\mathbf{e} \mathrm{RD}$ vs minimum temperature; $\mathbf{f} \mathrm{RW}$

vs minimum temperature; $\mathbf{g}$ RD vs maximum temperature; $\mathbf{h}$ RW vs maximum temperature 


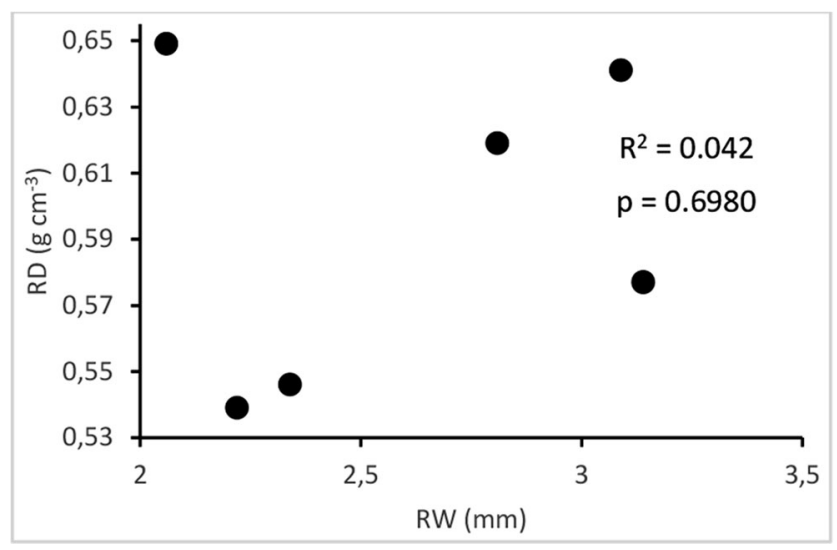

Fig. 7 Linear regression between RW and RD at the site level

analyses and lower in Vila Pouca de Aguiar and Manteigas, particularly for the peripheral analysis (mature wood), which corresponds to the more valuable part of the tree. Therefore, the wood produced in Vila Pouca de Aguiar and Manteigas has higher quality, particularly for utilization in highly valuable products such as plywood and veneer wood.

To complement information concerning the relationship between wood features and climate, a global analysis was performed with the density, growth and climatic components to infer the association among them, based on the principal component analysis (Fig. 8). Factor 1 (53.4\%) associated wood density with temperatures in opposition to altitude and precipitation, while factor $2(22.2 \%)$ is independent of the temperature and separated the growth components from the density components. This analysis also shows that the temperature effect is higher for the density components than for the growth components, as previously referred to in Fig. 6.

Finally, based on all the available information, a higherlevel analysis (multivariate discriminant analysis) was performed to provide a global view of variation in the dataset structure, namely the discriminant capacity of the Sites effect and the climatic characteristics (R, T, Tmin and Tmax) on

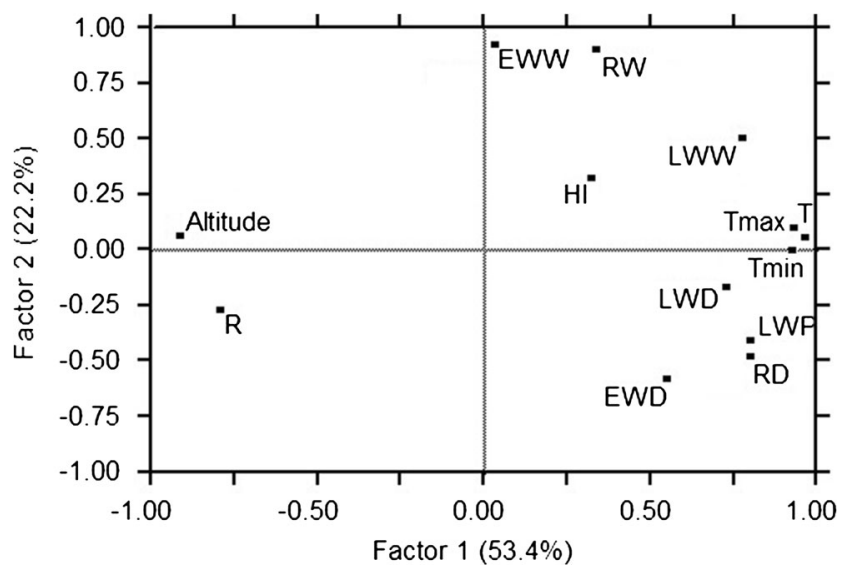

Fig. 8 Distribution of the wood components and climate variables over the first two factors of the principal components analysis variation of RD and RW (Table 7). This analysis was performed at the tree level for the six P. nigra sites in Portugal.

Although all the site and climate variables reveal a statistically significant discriminative capacity, maximum temperature (Tmax) shows higher discrimination ( $11.1 \%$ discriminant misclassification rate-Fig. 10), while altitude shows lower discrimination (18.9\% discriminant misclassification rate).

\subsection{Within- and between-tree variation}

In the analysis of the common 50 rings (Table 4), the highest RD values were found in Paredes de Coura and Caminha and the lowest in Manteigas and Vale do Zêzere. This Sites effect explains $9.11 \%$ of the total variation in RD, expressed mainly in the latewood components $\operatorname{MaxD}(6.82 \%), \operatorname{LWD}(7.35 \%)$ in contrast to the earlywood components $\operatorname{MinD}(4.33 \%)$ and EWD (4.9\%). The present results have been reported for resinous and broadleaf species (Louzada 2000; Tavares et al. 2014). Regarding LWP, the Sites effect explains 13.59\%, resulting in higher differences between sites (Table 3). This is in concordance with the RD variance, higher LWP values for Paredes de Coura and Caminha and lower values for Vale do Zêzere and Manteigas.

The Sites effect for $\mathrm{HI}$ has a value of $5.74 \%$, justifying the slight differences detected in Manteigas, Vila Pouca de Aguiar and Caminha, which have higher heterogeneity levels compared to the remaining sites. This value is higher than the result obtained by Louzada (2000), with $2.59 \%$ for P. pinaster.

Concerning the growth components, the Sites effect for RW, EWW and LWW contributes between 5.23 and $9.27 \%$ of the total variation. This effect is felt in Campeã and Caminha with higher growth values, in contrast to Paredes de Coura and Manteigas with lower growth.

The effect of Trees/Sites comprises the main source of variation for the three subsets (i.e., common core and peripheral analysis), with values between 54.06 and $85.86 \%$ of the total variation for the density components. In P. pinaster, the observed values are lower, with $11.5 \%$ (Louzada 1991) and $35.8 \%$ (Louzada 2000), as in the A. balsamea, with $23.8 \%$ (Koga and Zhang 2004). This agrees with the results of a study by Franceschini et al. (2010) on Norway spruce, which concluded that the RD variation was mainly located at the tree level (31.7\%), significantly higher than the site level (12.2\%). Due to the unknown genetic structure of the sampled stands, the variation between trees cannot be ascertained as genetic or environmental, as it is just possible to quantify the total phenotypic variation. Even so, it is expected that this high tree effect (tree variability) will allow good genetic gains in a future genetic program for improvement of wood characteristics (Zobel and Talbert 1984; Zobel and Jett 1995).

By separately analyzing juvenile (core analysis) and mature wood (peripheral analysis), it was possible to assess that this effect is higher in the earlywood components of mature 
Table 4 Summary of the ANOVA for the wood density and growth components for the three data subsets. The analysis comprises: degrees of freedom $(d f)$, expected variance (contribution of each source of variation for the total variation, in percentage) and the $\mathrm{F}$ significance value $(* * * p<0.001 ; * * p<0.01 ; * p<0.05 ;$ ns $p>0.05)$

\begin{tabular}{|c|c|c|c|c|c|c|c|c|c|c|c|}
\hline Source of variation & $d f$ & $\mathrm{RD}$ & MinD & MaxD & EWD & LWD & $\mathrm{HI}$ & RW & EWW & LWW & LWP \\
\hline \multicolumn{12}{|c|}{ Common Rings ( $1-50$ - cambial age) } \\
\hline Sites & 5 & $9.11 * * *$ & $4.33 * * *$ & $6.82 * * *$ & $4.90 * * *$ & $7.35 * * *$ & $5.74 * * *$ & $5.75 * * *$ & $5.23 * * *$ & $9.27 * * *$ & $13.59 * * *$ \\
\hline Trees/Sites & 84 & $67.27 * * *$ & $70.99 * * *$ & $72.61 * * *$ & $72.11 * * *$ & $72.22 * * *$ & $66.49 * * *$ & $33.95 * * *$ & $33.03 * * *$ & $34.06 * * *$ & $41.76 * * *$ \\
\hline Rings & 49 & $6.88 * * *$ & $5.39 * * *$ & $1.52 * * *$ & $4.38 * * *$ & $2.44 * * *$ & $4.64 * * *$ & $32.48 * * *$ & $32.83 * * *$ & $17.92 * * *$ & $13.94 * * *$ \\
\hline $\mathrm{RxS}$ & 245 & $3.17 * * *$ & $2.69 * * *$ & $1.93 * * *$ & $2.61 * * *$ & $1.86 * * *$ & $2.79 * * *$ & $6.78 * * *$ & $7.28 * * *$ & $3.09 * * *$ & $2.94 * * *$ \\
\hline Residual & 4116 & 13.56 & 16.60 & 17.12 & 16.00 & 16.13 & 20.34 & 21.04 & 21.63 & 35.66 & 27.77 \\
\hline \multicolumn{12}{|c|}{ Core Ring Analysis (1-25 - cambial age) } \\
\hline Sites & 5 & $11.45 * * *$ & $7.30 * * *$ & $10.54 * * *$ & $6.93 * * *$ & $11.06 * * *$ & $13.84 * * *$ & $15.47 * * *$ & $14.14 * * *$ & $14.60 * * *$ & $16.81 * * *$ \\
\hline Trees/Sites & 84 & $59.68 * * *$ & $62.71 * * *$ & $64.38 * * *$ & $62.99 * * *$ & $62.80 * * *$ & $54.06 * * *$ & $32.03 * * *$ & $31.39 * * *$ & $25.21 * * *$ & $32.43 * * *$ \\
\hline Rings & 24 & $3.51 * * *$ & $1.95 * * *$ & $3.04 * * *$ & $2.35 * * *$ & $3.80 * * *$ & $9.60 * * *$ & $19.50 * * *$ & $18.41 * * *$ & $15.56 * * *$ & $9.48 * * *$ \\
\hline $\mathrm{R} \times \mathrm{S}$ & 120 & $3.45 * * *$ & $1.97 * * *$ & $2.52 * * *$ & $2.45 * * *$ & $2.24 * * *$ & $1.82 * * *$ & $6.12 * * *$ & $6.25 * * *$ & $2.42 * * *$ & $2.18 * * *$ \\
\hline Residual & 2016 & 21.92 & 26.08 & 19.53 & 25.28 & 20.10 & 20.67 & 26.88 & 29.82 & 42.21 & 39.09 \\
\hline \multicolumn{12}{|c|}{ Peripheral Ring Analysis (outer 25 - chronological years) } \\
\hline Sites & 5 & $9.48 * * *$ & $1.60 \mathrm{NS}$ & $13.93 * * *$ & $2.07 *$ & $12.32 * * *$ & $6.77 * * *$ & $15.82 * * *$ & $13.65 * * *$ & $19.08 * * *$ & $14.54 * * *$ \\
\hline Trees/Sites & 84 & $76.89 * * *$ & $85.50 * * *$ & $63.43 * * *$ & $85.86 * * *$ & $64.74 * * *$ & $71.82 * * *$ & $51.03 * * *$ & $50.54 * * *$ & $48.20 * * *$ & $47.53 * * *$ \\
\hline Years & 24 & $0.95 * * *$ & $1.68 * * *$ & $1.67 * * *$ & $1.12 * * *$ & $0.99 * * *$ & $2.43 * * *$ & $8.50 * * *$ & $9.55 * * *$ & $4.81 * * *$ & $2.74 * * *$ \\
\hline $\mathrm{Y} \times \mathrm{S}$ & 120 & $1.86 * * *$ & $0.96 * * *$ & $2.15 * * *$ & $0.86 * * *$ & $2.03 * * *$ & $1.90 * * *$ & $6.32 * * *$ & $7.89 * * *$ & $3.61 * * *$ & $1.98 * * *$ \\
\hline Residual & 2016 & 10.83 & 10.25 & 18.82 & 10.10 & 19.92 & 17.08 & 18.33 & 18.38 & 24.31 & 33.21 \\
\hline
\end{tabular}

wood (MinD: $85.5 \%$ and EWD: $85.86 \%$ ). Similar trends were detected for the growth components. In this sense, the differences among sites (environmental effects) mainly influence the latewood components, while the differences between trees within each site mainly influence the earlywood components. Similar results were found by Louzada and Fonseca (2002), Koga and Zhang (2004), Gaspar et al. (2008) and Guller et al. (2012). In spring during earlywood development, the climatic conditions are stable, allowing higher expression of intra-tree variation. In the summer (latewood growth), climatic events, especially the water deficit of the Mediterranean climate (Martín-Benito et al. 2010a), interact with the genetic effects, decreasing the influence of the latter. Although the Trees/Sites effect was slightly higher in the peripheral analysis (47.53 to $85.86 \%$ ) than in the core analysis (25.21 to $64.38 \%$ ), the detected differences do not justify a delay of the trees' performance evaluation, namely for the wood density components.

Similarly, Gaspar et al. (2008) concluded that for $P$. pinaster, it is possible from the sixth year to perform a selection of trees, achieving similar outcomes to Louzada (2003) for the same species.

In regard to HI, the Trees/Sites effect is the main source of variation, mostly in the peripheral analysis, with a value of $71.82 \%$. For $P$. pinaster, Louzada (2000) achieved a lower result of $22.07 \%$, which could allow a better HI evaluation in P. nigra of individual tree performance in the mature wood. Concerning the growth components, the Trees/Sites effects is lower than the density components but is the main source of variation (33.03 to $41.76 \%)$. In $P$. pinaster wood, Louzada (2000) obtained $28.5 \%$ (LWP) and $34.1 \%$ (RW).

Although in other species, the Rings effect is usually high (Zobel and Van Buijtenen 1989), in the present case, it explains only $6.88 \%$ of the RD and was more significant for the earlywood than for the latewood components. This effect is due to the density radial pattern (Fig. 2), which has an initial decrease and subsequent increase in the later rings. This radial trend is similar in RD and EWD. For other resinous species such as $P$. radiata and $P$. sylvestris, the density pattern behaves likewise, with low values in the inner 10 growth rings, increasing from pith to bark (Cown 1980; Fernandes et al. 2017). According to Zobel and Van Buijtenen (1989), this is the most common density radial pattern in conifer species.

Furthermore, although the juvenile wood is characteristically highly heterogeneous, in the core analysis, the radial variation (Rings effect) is generally low, with 1.95 to $3.80 \%$ for the density components. Compared to $P$. pinaster wood (Louzada 2000), higher values were found (up to 54.98\%). As expected, in the mature wood (peripheral analysis for the last 25 chronological years), the radial variation had a lower effect on the density components ( 0.95 to $2.43 \%$ ), manifested by a stabilizing trend characteristic in this type of wood. Therefore, these results reflect high radial density homogeneity of $P$. nigra, both in juvenile and mature wood (Figs. 2, 3 and 4). This aspect is of major importance from the wood technological aptitude point of view, since the high radial heterogeneity of juvenile wood hampers its noble uses (Haygreen and 


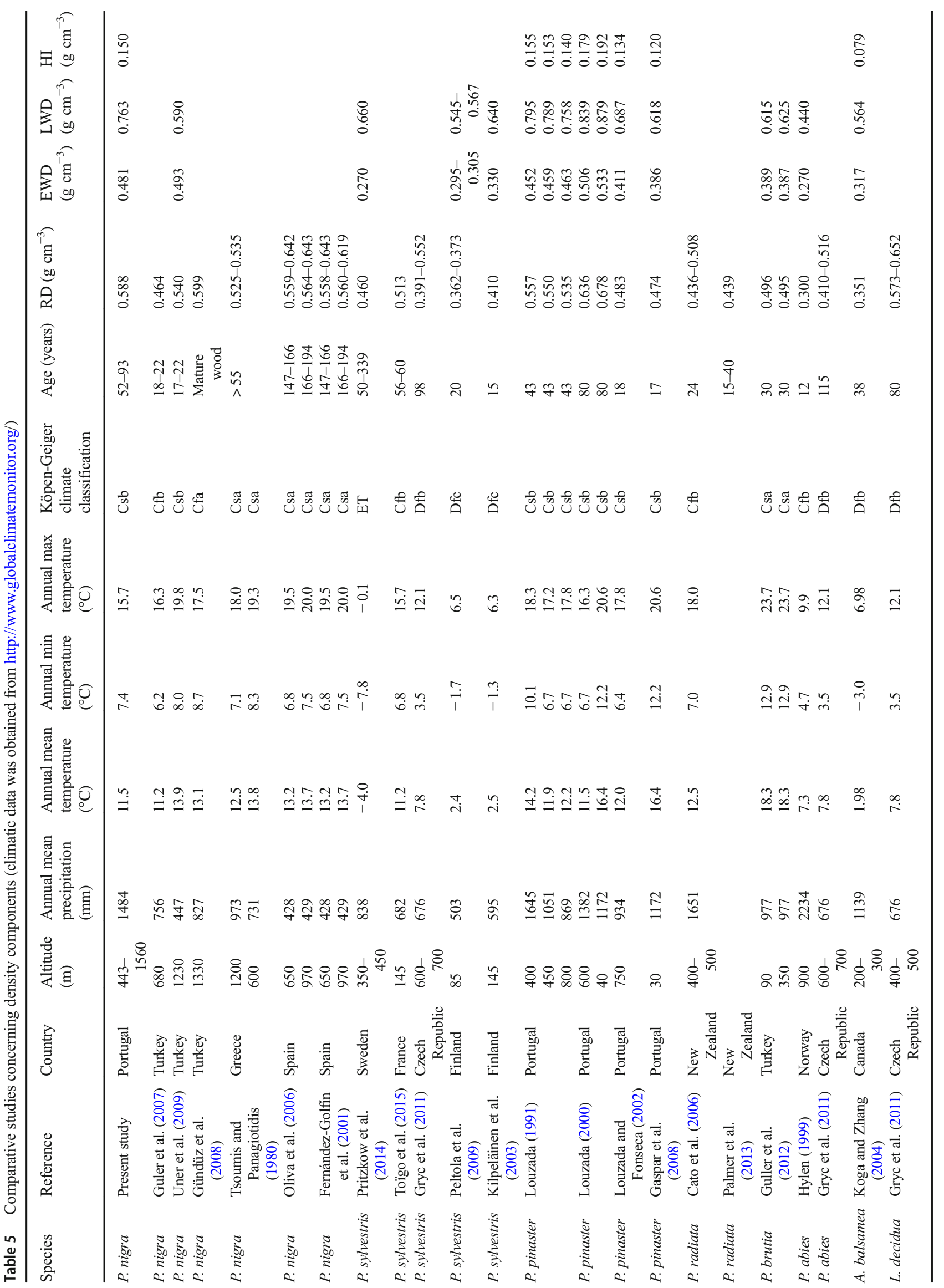




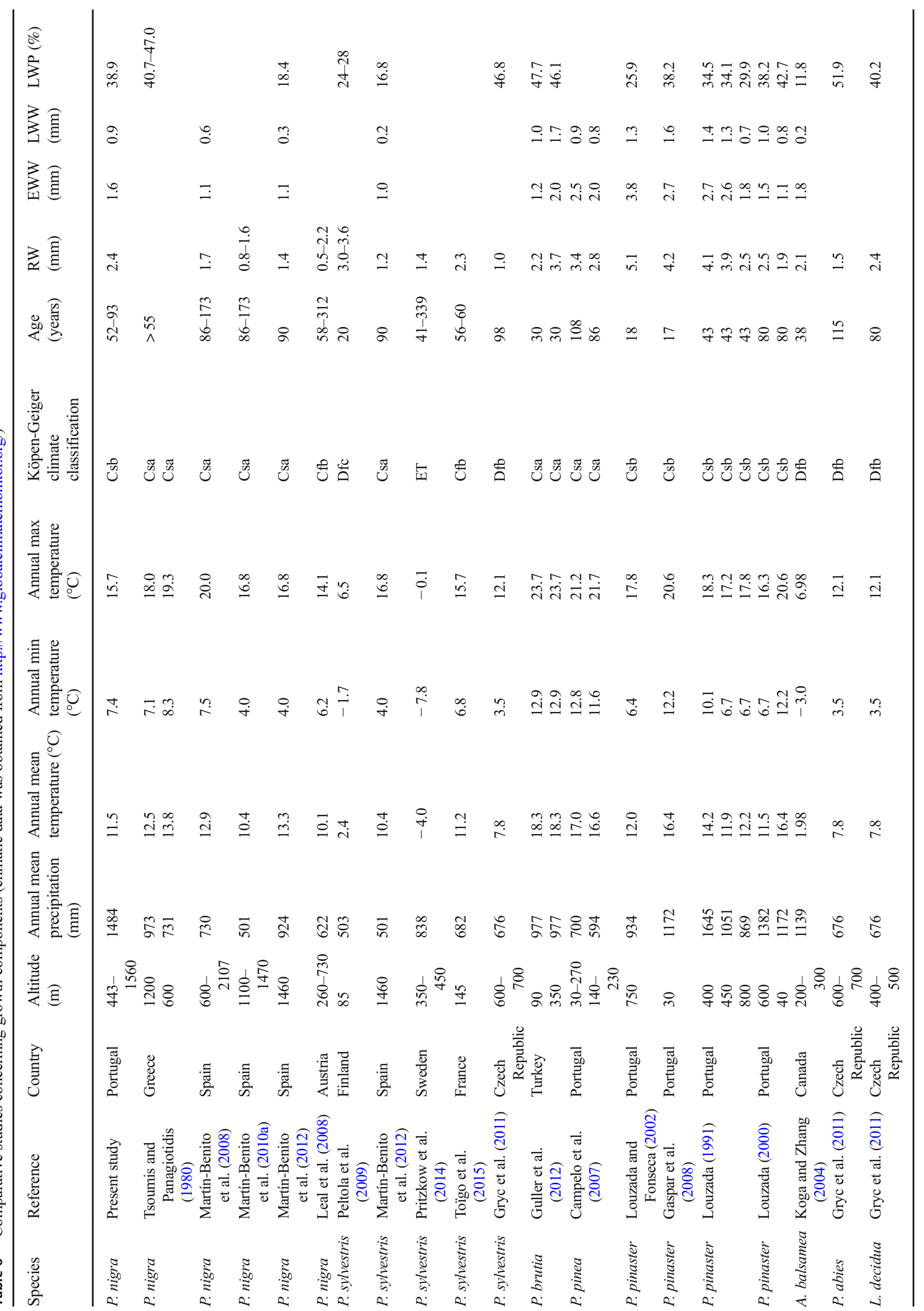



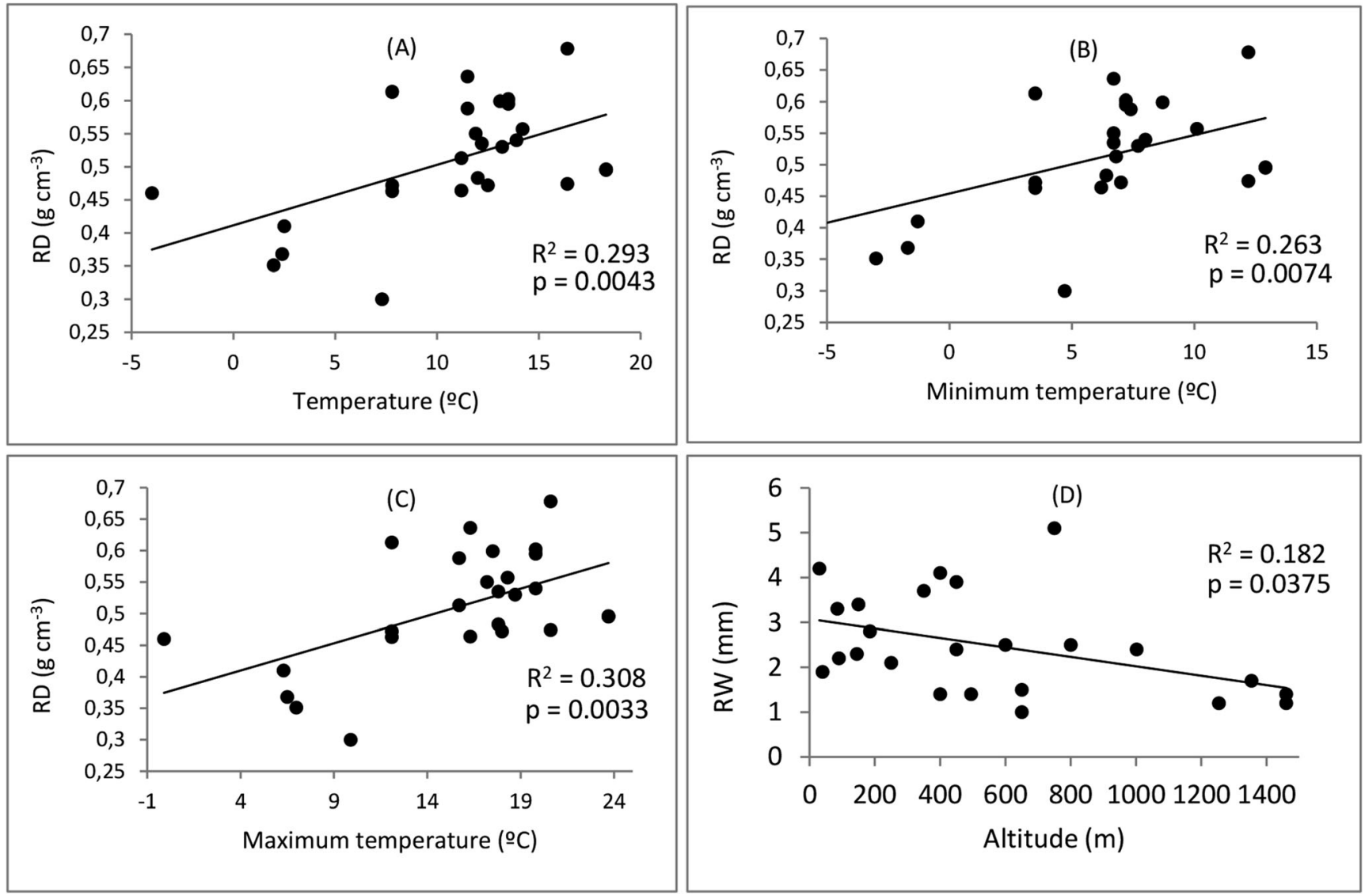

Fig. 9 Linear regression between wood components and climatic factors at the site and species level. a RD vs temperature; b RD vs minimum temperature; $\mathbf{c}$ RD vs maximum temperature; $\mathbf{d}$ RW vs altitude

Bowyer 1982; Zobel and Van Buijtenen 1989; Zobel and Sprague 1998).

Concerning HI, there is a low Rings effect (4.64\%), justified by a typical trend of low heterogeneity in the first years (juvenile wood) followed by an increase and subsequent decrease in the mature wood due to the minor early-latewood differences (Fig. 3). This later stage comprises the production of enhanced wood with low heterogeneity and high density. Compared to other species, a similar Rings effect was found in A. meloxycon (5.6\%), with an increase in the first years (three to five) and a consecutive decrease (Tavares et al. 2014). Concerning P. pinaster (Louzada 2000), the pattern is similar but with a stronger Rings effect $(28.33 \%)$. Therefore, it is possible to conclude that $P$. nigra wood presents higher density homogeneity among rings (juvenile/mature wood) and within rings (earlywood/latewood) when compared to P. pinaster.

Although the Rings effect is weak in the density components, it is higher on the growth components (RW, EWW, LWW), generally expressed by a pattern of decrease of the

Table 7 Discriminant analysis of site and climatic variables for the wood density and growth features

\begin{tabular}{llll}
\hline Classification Model & Wilks' Lambda & Multivariate $p$ value & $\begin{array}{c}\text { Discriminant } \\
\text { misclassification rate }\end{array}$ \\
\hline $\begin{array}{l}\text { Site (Paredes de Coura, Caminha, Vila Pouca de Aguiar, } \\
\quad \text { Campeã, Manteigas, Vale do Zêzere) }\end{array}$ & 0.0411447 & $<0.0000$ & $18.9 \%$ \\
Altitude $(<500 ; 500-1000 ;>1000)$ & 0.1916696 & $<0.0000$ & $14.4 \%$ \\
R $(<1300 ; 1300-1500 ;>1500)$ & 0.2128733 & $<0.0000$ & $14.4 \%$ \\
T $(<10 ; 10-13 ;>13)$ & 0.1916696 & $<0.0000$ & $14.4 \%$ \\
Tmin $(<6 ; 6-8 ;>8)$ & 0.1916696 & $<0.0000$ & $14.4 \%$ \\
$\operatorname{Tmax}(<14 ; 14-18 ;>18)$ & 0.192397 & $<0.0000$ & $11.1 \%$ \\
\hline
\end{tabular}


Fig. 10 Trees distribution by maximum temperature (Tmax) according to multivariate discriminant analysis performed with all wood density and growth components and grouped by three categories of maximum temperature $\left(\operatorname{Tmax}<14^{\circ} \mathrm{C}\right.$; $14{ }^{\circ} \mathrm{C}<\operatorname{Tmax}<18{ }^{\circ} \mathrm{C}$; Tmax $\left.>18{ }^{\circ} \mathrm{C}\right)$

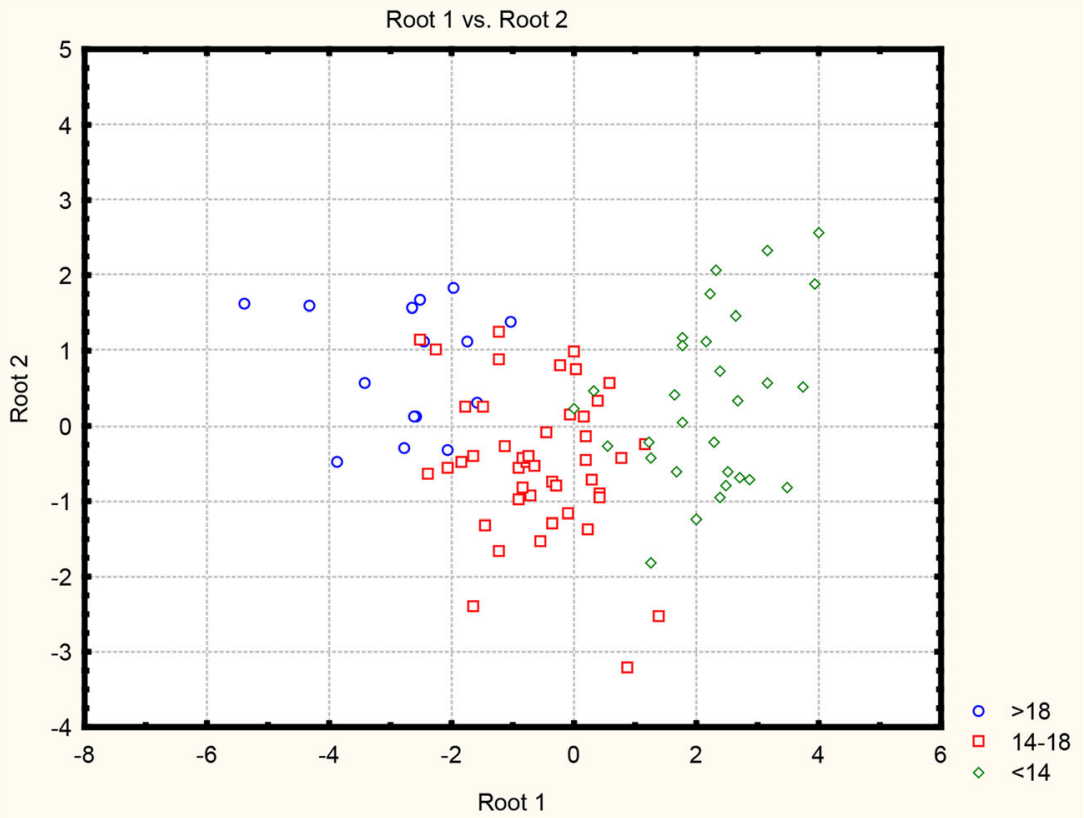

growth components with age (Fig. 4). A similar trend was detected in both resinous and broadleaf species (Zobel and Van Buijtenen 1989). The Rings effect on the LWP is $13.94 \%$, displayed by a progressive increase from pith to bark, similar to P. pinaster (Louzada 1991; Louzada 2000), P. brutia (Guller et al. 2012), A. balsamea (Koga and Zhang 2004) and P. nigra and P. sylvestris (Martín-Benito et al. 2012).

The interaction between $\mathrm{R} \times \mathrm{S}$ effects is generally low for the density components in the three subsets (0.86 to $3.45 \%$ ), indicating that the variation of radial density pattern is similar among the different sites. Concerning the growth characteristics, similar situation occurs, except for the EWW and RW, which present a slight stronger effect, not above $7.89 \%$.

Other effects not considered in the sources of variation are seen in the residual values, ranging from 10.10 to $26.08 \%$ (density components) and 18.33 to $42.21 \%$ (growth components).

\section{Conclusions}

Other studies performed on P. nigra in other European regions have observed a tendency of density increase from East (Turkey) to West (Portugal) although in terms of latitude, no effect was identified. Concerning meteorological effects, general trends of increased density with temperature and a decrease of RW with altitude were observed. Compared to other resinous species in Portugal, $P$. nigra revealed higher density, identical radial growth (RW) and heterogeneity between earlywood and latewood (higher HI), which comprises advantages in terms of the wood's workability.
Concerning the differences among the Portuguese sites, a tendency of a decrease in density with altitude and an increase with latitude was detected. Conversely, no effect was detected in radial growth in terms of altitude or latitude. The wood produced in Caminha and Vila Pouca de Aguiar showed both good radial growth and high density, indicating that it is highly valuable for general uses with high requirements in terms of mechanical performance, such as lumber and timber beams. On the other hand, the wood produced in Vila Pouca de Aguiar and Manteigas presented the lowest heterogeneity values among growth rings (HI), indicating that it is useful for the production of highly valuable products that demand high density homogeneity within rings, such as plywood and veneer wood.

The Trees/Sites effect was the main source of variation for all traits, while the Sites effect was more evident in the latewood (MaxD and LWD) than in the earlywood components (MinD and EWD). The radial variation effect was relatively reduced in the density components (lower than $6.88 \%$ of the total variance) and stronger in the growth components (between 2.74 and $32.83 \%$ ). This radial variation on the density components is expressed by a tendency of reduction in the first 8 years, followed by an increase to the periphery, while in the growth components, there is a decreasing trend from pith to bark. However, even in the juvenile wood, this radial variation is very low, meaning that this wood can be used for the same $P$. pinaster end products or for other enhanced uses.

From juvenile to mature wood, a reduction of the Rings (or Years) effect was detected, compensated by an increase of the Sites effect (usually in the latewood components) and Trees effect (mainly in the earlywood components). Therefore, it is possible to conclude that environmental factors (Sites effect) 
manifest more strongly in the latewood components (MaxD and LWD) while the Trees/Sites effect is more strongly expressed in the earlywood components (MinD and EWD).

Efforts have been made to find alternative sources for end forestry products that require multidisciplinary characterizations, including wood density and growth. Facing a reduction of the forest area comprising resinous species, black pine could be useful for the reforestation of Southern European mountainous areas that are not favourable for other species, namely $P$. pinaster, and could become an important alternative source for the Portuguese forestry sector.

Funding This work was funded by the Portuguese Foundation for Science and Technology (Fundação para a Ciência e a Tecnologia, FCT) under the project UID/AGR/04033/2013 and POCI-01-0145FEDER-006958 and co-financed by the Social European Fund (FSE) under the POPH-QREN (grant number SFRH/BD/91781/2012 to A. D. and SFRH/BPD/68932/2010 to A. C.).

\section{Compliance with ethical standards}

Conflicts of interest The authors declare that they have no conflicts of interest.

\section{References}

Amarasekara H, Denne MP (2002) Effect of crown size on wood characteristics of Corsican pine in relation to definitions of juvenile wood, crown formed wood and core wood. Forestry 75:51-61

Andreu L, GutiéRrez E, Macias M, Ribas M, Bosch O, Camarero JJ (2007) Climate increases regional tree-growth variability in Iberian pine forests. Glob Chang Biol 13:804-815

Barbéro M, Loisel R, Quézel P, Richardson DM, Romane F (1998) Pines of Mediterranean basin. In: Richardson DM (ed) Ecology and biogeography of Pinus. Cambridge University Press, pp 153-170

Boden DI (1982) The relationship between timber density of the three major pine species in the Natal midlands and various site and tree parameters. In: Wattle Research Institute (ed) Report 1981-1982. University of Natal, pp 160-126

Bogino SM, Bravo F (2008) Growth response of Pinus pinaster Ait. to climatic variables in central Spanish forests. Ann Forest Sci 65:506506

Campelo F, Nabais C, Freitas H, Gutiérrez E (2007) Climatic significance of tree-ring width and intra-annual density fluctuations in Pinus pinea from a dry Mediterranean area in Portugal. Ann For Sci 64: 229-238

Cato S, McMillan L, Donaldson L, Richardson T, Echt C, Gardner R (2006) Wood formation from the base to the crown in Pinus radiata: gradients of Tracheid Wall thickness, wood density, radial growth rate and gene expression. Plant Mol Biol 60:565-581

Climent J, Costa e Silva F, Chambel MR, Pardos M, Almeida MH (2009) Freezing injury in primary and secondary needles of Mediterranean pine species of contrasting ecological niches. Ann Forest Sci 66: 407-407

Cown DJ (1974) Physical properties of Corsican pine grown in New Zealand. N Z J For Sci 4:76-93

Cown DJ (1980) Radiata pine: wood age and wood property concepts. N Z J For Sci 10:504-507
Downes G, Evans R, Schimleck L, Fritts H (2000) The commercial cambium: understanding the origin of wood property variation. Exptl Biol Rev 123:325-336

Elliott GK (1970) Wood density in conifers. Commonwealth Forest Bureau

Fernandes C, Gaspar MJ, Pires J, Silva ME, Carvalho A, Brito JL, Lousada JL (2017) Within and between-tree variation of wood density components in Pinus sylvestris at five sites in Portugal. Eur J Wood Prod 75:511-526

Fernandéz A, Génova M, Creus J, Gutiérrez E (1996) Dendroclimatological investigation covering the last 300 years in Central Spain. In Dean JS, Meko DM and Swetnam TW (eds) Tree rings, environment and humanity. Radiocarbon, pp 181-190

Fernández-Golfín JI, Díez MR, Hermoso E, Gutiérrez A, Hermoso E, Conde M, Van den Eynde V (2001) Caracterización de la calidad y las propiedades de la madera de pino laricio (Pinus nigra Arn. salzmannii). Forest Syst 10:311-331

Ferrand JC (1982) Réflexions sur la densité du bois. 2iéme partie: calcul de la densité et de son hétérogénéité. Holzforschung 36:153-157

Franceschini T, Bontemps J, Gelhaye P, Rittie D, Herve J, Gegout J, Leban J (2010) Decreasing trend and fluctuations in the mean ring density of Norway spruce through the twentieth century. Ann For Sci 67:816

Gapare WJ, Wu HX, Abarquez A (2006) Genetic control of the time of transition from juvenile to mature wood in Pinus radiata D. Don. Ann For Sci 63:871-878

Gaspar MJ, Louzada JL, Silva ME, Aguiar A, Almeida MH (2008) Age trends in genetic parameters of wood density components in 46 halfsibling families of Pinus pinaster. Can J For Res 38:1470-1477

Gaspar MJ, Lousada JL, Rodrigues JC, Aguiar A, Almeida MH (2009) Does selecting for improved growth affect wood quality of Pinus pinaster in Portugal? For Ecol Manag 258:115-121

Génova M (2000) Anillos de crecimiento y años característicos en el Sistema Central (España) durante los últimos cuatrocientos años. Bol R Soc Esp Hist Nat Sec Geol 96:33-42

Génova M, Fernandéz Á (1998) Tree rings and climate of Pinus nigra subsp. salzmannii in Central Spain. Dendrochronologia 16-17:7585

Gryc V, Vavrcík K, Horn K (2011) Density of juvenile and mature wood of selected coniferous species. J For Sci 57:123-130

Guler C, Copur Y, Akgul M, Buyuksari U (2007) Some chemical, physical and mechanical properties of juvenile wood from black pine (Pinus nigra Arnold) plantations. J Appl Sci 7:755-758

Guller B, Isik K, Cetinay S (2012) Variations in the radial growth and wood density components in relation to cambial age in 30-year-old Pinus brutia ten. at two test sites. Trees 26:975-986

Gündüz G, Korkut S, Korkut DS (2008) The effects of heat treatment on physical and technological properties and surface roughness of Camiyanı black pine (Pinus nigra Arn. Subsp. pallasiana var. pallasiana) wood. Bioresour Technol 99:2275-2280

Haygreen J, Bowyer J (1982) Forest products and wood science - an introduction. The Iowa State University Press, Ames

Hylen G (1999) Age trends in genetic parameters of wood density in young Norway spruce. Can J For Res 29:135-143

ICNF (2013) IFN6 Inventário Florestal Nacional - Áreas de uso de solo e das espécies florestais de Portugal continental. Resultados preliminares. Instituto da Conservação da Natureza e das Florestas, Lisboa 34pp

Kilpeläinen A, Peltola H, Ryyppo A, Sauvala K, Laitinen K, Kellomaki S (2003) Wood properties of scots pines (Pinus sylvestris) grown at elevated temperature and carbon dioxide concentration. Tree Physiol 23:889-897

Knapic S, Louzada JL, Leal S, Pereira H (2007) Radial variation of wood density components and ring width in cork oak trees. Ann For Sci 64:211-218 
Koga S, Zhang SY (2004) Inter-tree and intra-tree variations in ring width and wood density components in balsam fir (Abies balsamea). Wood Sci Technol 38:149-162

Koprowski M, Duncker P (2012) Tree ring width and wood density as the indicators of climatic factors and insect outbreaks affecting spruce growth. Ecol Indic 23:332-337

Köse N, Akkemik Ü, Dalfes HN, Özeren MS, Tolunay D (2012) Treering growth of Pinus nigra Arn. Subsp. pallasiana under different climate conditions throughout western Anatolia. Dendrochronologia 30:295-301

Leal S, Eamus D, Grabner M, Wimmer R, Cherubini P (2008) Tree rings of Pinus nigra from the Vienna basin region (Austria) show evidence of change in climatic sensitivity in the late 20th century. Can J For Res 38:744-759

Lebourgeois F (2000) Climatic signals in earlywood, latewood and total ring width of Corsican pine from western France. Ann For Sci 57: $155-164$

Li X, Wu HX, Southerton SG (2011) Transcriptome profiling of wood maturation in Pinus radiata identifies differentially expressed genes with implications in juvenile and mature wood variation. Gene 487: $62-71$

Little EL, Critchfield WB (1969) Subdivisions of the Genus Pinus (pines). Washington, U.S. Department of Agriculture, Forest Service

Louro V (1982) O pinheiro larício (Pinus nigra Arnold) em Portugal. Direcção Geral do Ordenamento e Gestão Florestal

Louzada JL (1991) Variação nas componentes da densidade na madeira de Pinus pinaster Ait. [Variation of the wood density components of Pinus pinaster Ait.] Technical-Scientific series, Applied Sciences, no 12, UTAD, Vila Real, Portugal

Louzada JL (2000) Variação fenotípica e genética em características estruturais na madeira de Pinus pinaster Ait. O comprimento das fibras e a densidade até aos 80 anos de idade das árvores. Parâmetros genéticos na evolução juvenil - adulto das componentes da densidade da madeira. [Phenotypic and genetic variation in structural features in Pinus pinaster Ait wood. The fiber length and density to 80 years of a tree's age. Genetic parameters in juvenile-mature evolution of wood density components.] Didactic, Applied Science Series, No 143, UTAD, Vila Real, Portugal

Louzada JL (2003) Genetic correlations between wood density components in Pinus pinaster Ait. Ann For Sci 60:285-294

Louzada JL, Fonseca F (2002) The heritability of wood density components in Pinus pinaster Ait. And the implications for tree breeding. Ann For Sci 59:867-873

Martín-Benito D, Cherubini P, del Río M, Cañellas I (2008) Growth response to climate and drought in Pinus nigra Arn. trees of different crown classes. Trees 22:363-373

Martín-Benito D, Del Río M, Cañellas I (2010a) Black pine (Pinus nigra Arn.) growth divergence along a latitudinal gradient in western Mediterranean mountains. Ann For Sci 67:401

Martín-Benito D, Del Río M, Heinrich I, Helle G, Cañellas I (2010b) Response of climate-growth relationships and water use efficiency to thinning in a Pinus nigra afforestation. For Ecol Manag 259:967975

Martín-Benito D, Beeckman H, Cañellas I (2012) Influence of drought on tree rings and tracheid features of Pinus nigra and Pinus sylvestris in a Mesic Mediterranean forest. Eur $\mathrm{J}$ For Res 132:33-45

Mothe F, Sciama D, Leban JM, Nepveu G (1998) Localisation de la transition bois initial-bois final dans un cerne de chêne par analyse microdensitométrique. Ann For Sci 55:437-449

Mutz R, Guilley E, Sauter UH, Nepveu G (2004) Modelling juvenile-mature wood transition in scots pine (Pinus sylvestris L.) using nonlinear mixed-effects models. Ann For Sci 61:831-841
Oliva AG, Merino VB, Seco JI, García MC, Prieto EH (2006) Effect of growth conditions on wood density of Spanish Pinus nigra. Wood Sci Technol 40:190-204

Palmer DJ, Kimberley MO, Cown DJ, McKinley RB (2013) Assessing prediction accuracy in a regression kriging surface of Pinus radiata outerwood density across New Zealand. For Ecol Manag 308:9-16

Pazdrowski W (2004) The proportion and some selected physical and mechanical properties of juvenile, maturing and adult wood of black pine and scots pine. E J P A U 7

Pearson RG, Ross BE (1984) Growth rate and bending properties of selected loblolly pines. Wood Fiber Sci 16:37-47

Peltola H, Gort J, Pulkkinen P, Gerendiain AZ, Karppinen J, Ikonen VP (2009) Differences in growth and wood density traits in scots pine (Pinus sylvestris L.) genetic entries grown at different spacing and sites. Silva Fenn 43:339-354

Piutti E, Cescatti A (1997) A quantitative analysis of the interactions between climatic response and intraspecific competition in European beech. Can J For Res 27:277-284

Polge H (1966) Établissement des courbes de variation de la densité du bois par exploration densitométrique de radiographies d'échantillons prélevés à la tarière sur des arbres vivants: applications dans les domaines Technologique et Physiologique. Ann For Sci 23:1-206

Pritzkow C, Heinrich I, Grudd H, Helle G (2014) Relationship between wood anatomy, tree-ring widths and wood density of Pinus sylvestris L. and climate at high latitudes in northern Sweden. Dendrochronologia 32:295-302

Rossi S, Cairo E, Krause C, Deslauriers A (2015) Growth and basic wood properties of black spruce along an alti-latitudinal gradient in Quebec, Canada. Ann For Sci 72:77-87

Rozenberg P, Franc A, Cahalan C (2001) Incorporating wood density in breeding programs for softwoods in Europe: a strategy and associated methods. Silvae Genet 50:1-6

Rubiales JM, García-Amorena I, Hernández L, Génova M, Martínez F, Manzaneque FG, Morla C (2010) Late quaternary dynamics of pinewoods in the Iberian Mountains. Rev Palaeobot Palyno 162:476491

Rubio-Moraga A, Candel-Perez D, Lucas-Borja ME, Tiscar PA, Viñegla B, Linares JC, Gómez-Gómez L, Ahrazem O (2012) Genetic diversity of Pinus nigra Arn. Populations in southern Spain and northern Morocco revealed by inter-simple sequence repeat profiles. Int J Mol Sci 13:5645-5658

Steffenrem A (2008) Genetic variation in structural wood quality traits in Norway spruce and implications for tree breeding. Dissertation, Norwegian University of Life Sciences

Tavares F, Louzada JL, Pereira H (2014) Variation in wood density and ring width in Acacia melanoxylon at four sites in Portugal. Eur J For Res 133:31-39

Toïgo M, Vallet P, Tuilleras V, Lebourgeois F, Rozenberg P, Perret S, Courbaud B, Perot T (2015) Species mixture increases the effect of drought on tree ring density, but not on ring width, in Quercus petraea-Pinus sylvestris stands. For Ecol Manag 345:73-82

Tsoumis G, Panagiotidis N (1980) Effect of growth conditions on wood quality characteristics of black pine (Pinus nigra Arn.). Wood Sci Technol 14:301-310

Uner B, Oyar O, Var AA, Altnta OL (2009) Effect of thinning on density of Pinus nigra tree using X-ray computed tomography. J Environ Biol 30:359-362

Van der Maaten-Theunissen M, Boden S, Van der Maaten E (2013) Wood density variations of Norway spruce (Picea abies (L.) karst.) under contrasting climate conditions in southwestern Germany. Ann For Sci 56:91-103

Wils TH, Robertson I, Eshetu Z, Sass-Klaassen UG, Koprowski M (2009) Periodicity of growth rings in Juniperus procera from 
Ethiopia inferred from crossdating and radiocarbon dating. Dendrochronologia 27:45-58

Wu HX, Eldridge KG, Matheson AC, Powell MB, McRae TA, Butcher TB, Johnson IG (2007) Achievements in forest tree improvement in Australia and New Zealand 8. Successful introduction and breeding of radiata pine in Australia. Aust For 70:215-225

Xu P, Donaldson L, Walker J, Evans R, Downes G (2004) Effects of density and microfibril orientation on the vertical variation of lowstiffness wood in radiata pine butt logs. Holzforschung 58:673-677
Zobel BJ, Jett JB (1995) Genetics of wood production. Springer, Berlin Zobel BJ, Sprague JR (1998) Juvenile wood in Forest trees. Springer, Berlin

Zobel BJ, Talbert J (1984) Applied Forest tree improvement. John Wiley \& Sons

Zobel BJ, Van Buijtenen JP (1989) Wood variation and wood properties. Springer, Berlin 